II cell origin. Biochim Biophys Acta 617:36

34. McGarry DJ, Foster DW 1976 An improved and simplified radioisotopic assay for the determination of free and esterified carnitine. J Lipid Res 17:277

35. Myher JJ, Kuksis A, Marai L, Yeung SKF 1978 Microdetermination of molecular species of oligo- and polyunsaturated diacylglycerols by gas chromatography-mass spectrometry of their tert-butyl dimethylsilyl ethers. Anal Chem 50:557

36. Nikiforov A, Lohninger A, Specker M, Linhart L 1982 Studies on molecular species of dog lung $s n$-glycerol-3-phosphocholines by gas liquid chromatography-mass spectrometry and computer accumulated integrated field desorption mass spectrometry (FD-CAI MS). Eur J Mass Spectrom Biochem Med Environ Res 2:105

37. Picken JJ, Lurie M, Kleinerman J 1975 Prolonged glucocorticoid treatment in the rat: effects on pulmonary morphology, ultrastructure and elastic properties. Chest 67:48S

38. Possmayer F, Duwe G, Metcalfe R, Stewart-DeHaan PJ, Wong C, Heras JL, Harding PGR 1977 Cortisol induction of pulmonary maturation in the rabbit foetus: its effects on enzymes related to phospholipid biosynthesis and on marker enzymes for subcellular organelles. Biochem J 166:485

39. Possmayer F, Casola PG, Chan F, MacDonald P, Ormseth MA, Wong T, Harding PGR, Tokmakjian S 1981 Hormonal induction of pulmonary maturation in the rabbit fetus. Effects of maternal treatment with estradiol$17 \beta$ on the endogenous levels of cholinephosphate, CDP-choline and phosphatidylcholine. Biochim Biophys Acta 664:10

40. Post M, Batenburg JJ, van Golde LMG 1980 Effects of cortisol and thyroxine on phosphatidylcholine and phosphatidylglycerol synthesis by adult rat lung alveolar type II cells in primary culture. Biochim Biophys Acta 618:308

41. Rebouche CJ 1977 Carnitine movement across muscle cell membranes. Studies in isolated rat muscle. Biochim Biophys Acta 471:145
42. Rooney SA, Marino PA, Gobran LI, Gross I, Warshaw JB 1979 Thyrotropinreleasing hormone increases the amount of surfactant in lung lavage from fetal rabbits. Pediatr Res 13:623

43. Sanders RL, Engle MJ, Douglas WHJ 1981 Effect of dexamethasone upon surfactant phosphatidylcholine and phosphatidylglycerol synthesis in organotypic cultures of type II cells. Biochim Biophys Acta 664:380

44. Schönberger W. Grimm W, Emmrich P, Gempp W 1980 Thyroid administration lowers mortality in premature infants. Eur $J$ Pediatr 133:181

45. Smith BT, Torday JS, Giroud CJP 1974 Evidence for different gestationdependent effects of cortisol in cultured fetal lung cells. J Clin Invest 53:1518

46. Sundell HW, Gray ME, Relier JP, Swift LL, Stahlman MT 1979 The effects of ACTH on lung maturation in fetal lambs. Am J Pathol 97:393

47. Tao RC, Yoshimura NN 1980 Carnitine metabolism and its application in parenteral nutrition. J Parenter Enter Nutr 4:469

48. Van Golde LMG 1976 Metabolism of phospholipids in the lung. Am Rev Respir Dis 114:977

49. Van Heusden GPH, Noteborn HPJM, van den Bosch H 1981 Selective utilization of palmitoyl lysophosphatidylcholine in the synthesis of disaturated phosphatidylcholine in rat lung. A combined in vitro and in vivo approach. Biochim Biophys Acta 664:49

50. Wang NS, Kotas RV, Avery ME, Thurlbeck WM 1971 Accelerated appearance of osmiophilic bodies in fetal lungs following steroid injection. J Appl Physiol $30: 362$

51. Wolff J, Müller DM, Strack E 1971 Toxizität von L(-)-Carnitine und einigen Acylcarnitinen. Acta Biol Med Germ 26:1237

52. Wu B, Kikkawa Y, Onzalesi MM, Motoyama EK, Kaibara M, Zigas CJ, Cook $C D 1973$ The effect of thyroxine and the maturation of fetal rabbit lungs. Biol Neonate 22:161

\title{
Food Proteins and Gut Mucosal Barrier. II. Differential Interaction of Cow's Milk Proteins with the Mucous Coat and the Surface Membrane of Adult and Immature Rat Jejunum
}

\author{
M. STERN, K. Y. PANG, AND W. A. WALKER \\ Combined Pediatric Gastrointestinal and Nutrition Division, Massachusetts General Hospital, Children's \\ Hospital, Harvard Medical School, Boston, Massachusetts 02114
}

\begin{abstract}
Two in vitro intestinal models were used to investigate postnatal maturational changes of the gut barrier functions. Microvillus membrane (MVM) preparations were studied for surface binding, and everted gut sacs were studied for mucous coat binding, breakdown and uptake of radioiodinated bovine serum albumin (BSA), and $\beta$-lactoglobulin ( $\beta$-LG). Surface binding of these proteins to MVM was weak and nonspecific. There was more binding of both proteins to immature MVM (BSA: newborns, $2.74 \pm 0.52 \%$, adults, $1.08 \pm 0.17 \%, p<0.001 ; \beta$ LG: newborns, $6.30 \pm 0.54 \%$; adults, $2.05 \pm 0.07, p<$ 0.001). In contrast to MVM binding characteristics, mu-
\end{abstract}

Received February 1, 1984; accepted May 22, 1984

Requests for reprints may be addressed to Dr. Martin Stern, UniversitaetsKinderklinik, Martinistrasse 52, D-2000 Hamburg 20, Federal Republic of Germany.

This work was supported by grants from Deutsche Forschungsgemeinschaft (DFG Ste 305/2-1) and from the National Institutes of Health (AM 16269, GM 21700, and HD 12437). cous coat binding of the cow's milk proteins to immature gut sacs was significantly less (BSA: preweanlings, $0.94 \pm$ $0.30 \mu \mathrm{g}^{125}$-I-protein $\mathrm{Eq} / \mathrm{mg}$ mucosal protein; adults, 3.06 $\pm 0.74, p<0.001 ; \beta$-LG: preweanlings, $5.61 \pm 1.48$; adults, $9.83 \pm 1.33, p<0.001)$. Protein binding and uptake were correlated in the immature animals $(r=0.76, p<0.001$ for BSA and $r=0.85, p<0.001$ for $\beta$-LG). More $\beta$-LG was bound and taken up than BSA in the preweanlings ( $p$ $<0.001$ ). Trichloroacetic acid precipitation studies showed that, even in the immature rats, $\beta$-LG was much more readily broken down by mucosa-associated enzymes than BSA. Immature animals showed less protein breakdown than adult controls. Decreased protein breakdown and mucous coat binding as well as increased MVM binding may account for the increased uptake of intact food antigens in the newborn. Differences between increased MVM binding and decreased mucous coat binding of cow's milk proteins are attributed to protective elements such as the mucus layer which is present in the gut sac model but lacking in MVM. (Pediatr Res 18:1252-1256, 1984) 


\section{Abbreviations}

BSA, bovine serum albumin

$\beta$-LG, $\beta$-lactoglobulin

MVM, microvillus membrane

TCA, trichloroacetic acid

Hepes, 4-(2-hydroxyethyl)-1-piperazineethanesulfonic acid

Absorptive and barrier functions of the small intestine undergo pre- and postnatal maturation and differentiation. This developmental process has been studied extensively in the rat $(11,21)$. It is subject to modulations by multiple factors such as weaning and hormonal control (16). Studies in different experimental animal species have shown that intestinal maturation affects gut mucosal barrier functions such as macromolecular antigen handling in the everted gut sac model (34) and uptake of orally administered protein in the whole animal model $(13,32,33)$. The increased absorption of intact BSA during early postnatal age has been shown directly in rabbits, and it was shown to decrease significantly after $1 \mathrm{wk}$ of age (33). In the same postnatal period, the intestinal surface is undergoing structural and biochemical changes such as a decrease in fluidity of MVM and changes in binding capacity and kinetics of calcium, cholera toxin, and lectins $(5,19,23)$.

In a recent study of adult rats (29), a correlation has been found between the intestinal uptake and the binding to the mucous coat of cow's milk proteins including their breakdown products, using the everted gut sac model. Our present objective was to study the function of intestinal antigen handling in early postnatal age and determine if associations between changes on the surface membrane level (MVM model) and on the mucous coat level (gut sac model) existed and correlated with antigen uptake. The early postnatal age is of pediatric interest with respect to the uptake of food proteins (25), and to the development of food protein allergy or intolerance $(3,15)$.

\section{MATERIALS AND METHODS}

Animals. Adult female Sprague-Dawley rats (Charles River Laboratories, Wilmington, MA) ranging in weight from 200 to $250 \mathrm{~g}$ were kept on a milk protein-free rat chow (Ralston Purina Inc., St. Louis, MO) for at least $6 \mathrm{wk}$ and were fasted overnight prior to the study. Animals were sacrificed by cervical dislocation. Newborn animals weighing between 5 and $7 \mathrm{~g}$ were allowed to suckle and were sacrificed between 12 and $24 \mathrm{~h}$ of age. Eighteenday-old suckling rats (preweanlings) weighed between 30 and 40 g. Animals whose stomach contained chow were excluded from the study. Immature animals never had been fed cow's milk proteins.

Radiolabeled cow's milk proteins. BSA $(5 \times$ crystallized $)$ and $\beta$-LG ( $3 \times$ crystallized) were purchased from Sigma Chemical Co., St. Louis, MO. These proteins were found to be sufficiently pure (BSA; $98 \%$; $\beta$-LG, $100 \%$ ) by polyacrylamide gel electrophoresis (29). BSA and $\beta$-LG were labeled with $\mathrm{Na}^{125} \mathrm{I}$ using the Markwell technique (20). All radiochemicals were purchased from New England Nuclear, Boston, MA. Any free iodine was removed by gel filtration. The specific activity of labeled BSA and $\beta$-LG was $2.5 \mu \mathrm{Ci} / \mu$ g protein. Over $90 \%$ of the radioactivity was precipitated by $10 \%(\mathrm{w} / \mathrm{v}) \mathrm{TCA}$.

Microvillus membrane binding studies. MVM were prepared from newborn, 18-day-old, and adult rats by a modification of the $\mathrm{Ca}^{2+}$ precipitation method $(14,26)$. Fasted $(n=7)$, 18-dayold $(n=6)$, and newborn $(n=50)$ rats were sacrificed; the proximal small intestine was removed and washed with cold saline. Scrapings of adult or 18-day-old intestine and short pieces of newborn intestine were homogenized in $500 \mathrm{mM}$ mannitol, 10 mM Hepes buffer, pH 7.5 (all chemicals from Sigma). After
1:6 dilution and filtration through a fine nylon mesh, $\mathrm{CaCl}_{2}$ was added to a final concentration of $10 \mathrm{mM}$. The mixture was centrifuged at $2,500 \times \mathrm{g}$ for 15 minutes, the supernatant being saved and centrifuged at $28,000 \times \mathrm{g}$ for 30 minutes. The pellets were resuspended in $100 \mathrm{mM}$ mannitol, $10 \mathrm{mM}$ Hepes, pH 7.5 and centrifuged again at $28,000 \times \mathrm{g}$. Final pellets were suspended in $100 \mathrm{mM}$ mannitol, $10 \mathrm{mM}$ Tris- $\mathrm{HCl}, \mathrm{pH}$ 7.4. MVM protein concentration was determined (17), and sucrase (adult MVM) and lactase (newborn and 18-day MVM) activities were determined according to Dahlquist (7). Total yield of MVM preparations was between 1.7 and $2.0 \%$. The final ratio of specific disaccharidase activities of the purified MVM preparations compared to the initial homogenates (enrichment factor) was $20.6 \pm$ 2.0 in the adult and $28.0 \pm 5.0$ in the immature animals.

Preliminary binding studies were carried out using the Millipore filter separation technique $(6,12)$. The radioactivity on the filter membranes which was caused by binding of labeled BSA and $\beta$-LG to MVM could be washed away rapidly by small amounts of incubation buffer. Thus, in contrast to lectin binding studies (5), there were no consistent data obtained for BSA and $\beta$-LG binding using filter separation. Final binding studies had to be done using the miniature ultracentrifuge (Airfuge) separation technique (1). Airfuge tubes $(5 \times 20 \mathrm{~mm}$; Beckman Instruments, Inc., Spinco Division, Palo Alto, CA) were pretreated overnight at $4^{\circ} \mathrm{C}$ with $1 \mathrm{mg} / \mathrm{ml}$ solutions of cold BSA or $\beta$-LG to inhibit nonspecific protein adsorption from the final incubation mixture. For the incubations, protein solutions between $0.01 \mu \mathrm{g}$ and $1 \mathrm{mg} / \mathrm{ml}$ were used in Tris- $\mathrm{HCl}(30 \mathrm{mM}, \mathrm{pH}$ 7.4) containing $125 \mathrm{mM} \mathrm{NaCl}$. The solutions had been trace-labeled to yield $5 \times 10^{5} \mathrm{cpm} / \mathrm{ml}$. After samples for the original specific activity had been taken, $100 \mu \mathrm{l}$ of MVM suspensions varying in protein content between 0.1 and $4.0 \mathrm{mg} / \mathrm{ml}$ were mixed with the same volume of protein-label solution and incubated at $37^{\circ} \mathrm{C}$. All incubation experiments were run in duplicate. One hundred$\mu l$ aliquots of the mixture were then centrifuged at 30 p.s.i. for $15 \mathrm{~min}$ at $178,000 \times \mathrm{g}$ in a Beckman Airfuge, using the A-100/ 30 fixed angle rotor, to separate unbound protein from MVM. Supernatants were removed and pellets were counted. Duplicate Airfuge tubes were incubated with the protein-label solution and buffer $1: 1$. These tubes served as a control for nonspecific adsorption, their counts being subtracted from the total counts obtained with MVM. Final results were calculated from the original specific activity and expressed either as per cent ${ }^{125} \mathrm{I}$ protein Eq bound or as $\mu \mathrm{g}$ of ${ }^{125} \mathrm{I}$-protein $\mathrm{Eq} / \mathrm{mg}$ of $\mathrm{MVM}$ protein. Counts exceeding $200 \%$ of the control counts were only obtained using MVM protein concentrations above $0.5 \mathrm{mg} / \mathrm{ml}$. Thus, basic incubation experiments were carried out at a MVM protein concentration of $1.5 \mathrm{mg} / \mathrm{ml}$ ( $c f$. Fig. 3). Steady state for BSA and $\beta$-LG binding was reached after $30 \mathrm{~min}$, so that this time of incubation was used throughout the study. Inhibition experiments were done with cold BSA and $\beta-\mathrm{LG}$ at $1 \mathrm{mg} / \mathrm{ml}$ for 30 min prior to final incubation.

Everted gut sacs, binding, and uptake studies. Everted gut sacs of $5-\mathrm{cm}$ length were prepared from adult proximal jejunum according to Wilson and Wiseman (36). Gut sacs from newborn animals were too fragile to be handled during incubation. Sacs from 18-day-old animals were $10 \mathrm{~cm}$ long, but otherwise were prepared in the same way as the adult ones (34). Sacs were filled with $1 \mathrm{ml}$ and incubated in Erlenmeyer flasks containing $10 \mathrm{ml}$ of Tris- $\mathrm{HCl}$ buffer (30 mM, pH 7.4) with $\mathrm{NaCl}(125 \mathrm{mM})$ and fructose $(10 \mathrm{mM})$. Viability of the sacs was monitored by morphology and by the active uptake of ${ }^{45} \mathrm{Ca}, 3-O-\mathrm{D}-\left[\right.$ methyl $\left.-{ }^{3} \mathrm{H}\right]$ glucose, and aminocyclopentane- $1-\left[{ }^{14} \mathrm{C}\right]$ carboxylic acid (29). The final incubation fluid contained $1 \mathrm{mg} / \mathrm{ml}$ of BSA or $\beta$-LG. These solutions had been trace-labeled to yield $2 \times 10^{5} \mathrm{cpm} / \mathrm{ml}$. Incubations were done using a Dubnoff metabolic shaking water bath (Labline Inc., Chicago, IL) for up to $30 \mathrm{~min}$ at $37^{\circ} \mathrm{C}$ in an atmosphere of $100 \%$ oxygen. Nonspecific adsorption of protein to glass surfaces was taken into account by preincubating all incubation flasks with the labeled solutions for $30 \mathrm{~min}$, taking 
reference samples for specific activity before and after this preincubation. After 1 to $30 \mathrm{~min}$ of final incubating, gut sacs were removed from the flasks and blotted on filter paper. Sac contents were drained by syringe, the mucosa than being scraped using glass slides. Contents and scrapings were counted separately in a Gamma 7000 counter (Beckman Instruments Inc., Irvine, CA). Mucosal scrapings were homogenized and their protein content was determined (17). Results for binding and uptake were calculated from the original specific activity of the solutions, the figures being expressed as $\mu \mathrm{g}$ of ${ }^{125} \mathrm{I}$-labeled protein $\mathrm{Eq} / \mathrm{mg}$ of mucosal protein (29). Uptake was defined as the amount of radioactivity found inside the gut sacs. Binding was defined as the radioactivity found in mucosal scrapings.

One $\mathrm{ml}$ of the homogenized scrapings and the sac contents was subjected to precipitation by $10 \%(\mathrm{w} / \mathrm{v})$ TCA in the cold. Ten $\mu \mathrm{g}$ of cold protein were added as a carrier to the sac contents before precipitation. The amount of radioactivity precipitated was compared to the total radioactivity.

Statistical evaluation. Student's $t$ test and analysis of variance were used to assess statistical significance of differences. The $F$ distribution was used to compare slopes of the linear relation between MVM protein concentration and protein binding.

\section{RESULTS}

Binding of BSA and $\beta-L G$ by $M V M$. Because the radioactivity found with MVM after $30 \mathrm{~min}$ of incubation with the labeled protein was washed easily on a filter membrane, it was assumed that this activity represented binding and not uptake. There was no specific inhibition found by preincubating MVM with the cold proteins. More $\beta$-LG was bound than BSA $(p<0.001$, Fig. 1) by MVM preparations from newborn, 18-day-old, and adult rats. There was more binding of both proteins in the immature animals, compared to the mature ones, the figures increasing from newborn to preweanling age and then decreasing to the adult age.

The relation between protein concentration and MVM binding was studied in different ways. First, a constant concentration of MVM ( $1.5 \mathrm{mg} / \mathrm{ml}$ protein) was incubated with $10 \mu \mathrm{g} / \mathrm{ml}$ to 1

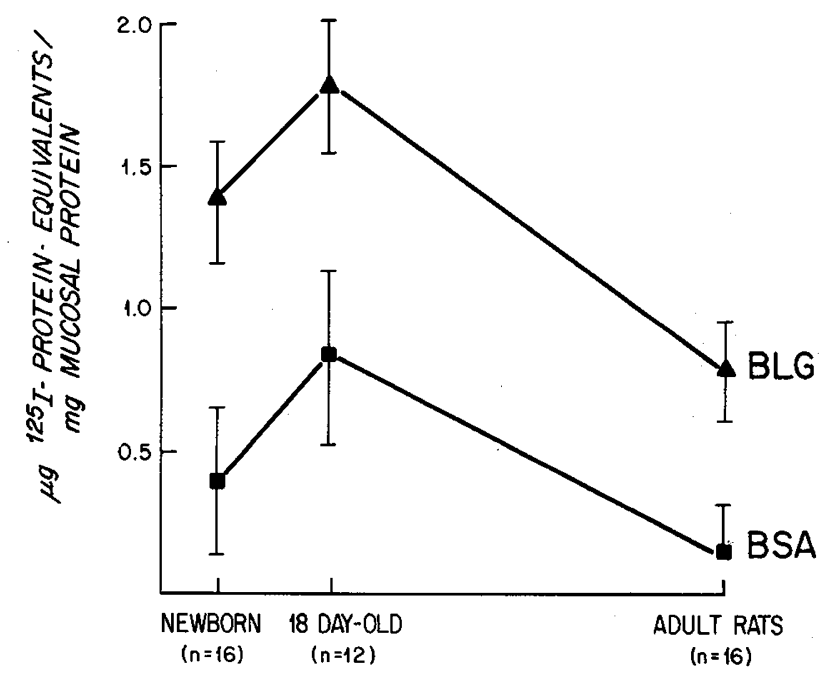

Fig. 1. Binding of ${ }^{125} \mathrm{I}-\mathrm{BSA}$ and $\beta$-LG by jejunal MVM: effect of maturity. Numbers of expriments are given in parentheses. Means \pm SD are shown. Protein concentration of BSA and $\beta-\mathrm{LG}, 0.1 \mathrm{mg} / \mathrm{ml}$; MVM protein concentration, $1.5 \mathrm{mg} / \mathrm{ml}$. Differences in binding between immature and adult groups are significant $\left(p<0.01,{ }^{*}\right)$ for BSA binding in newborns versus adults, highly significant $(p<0.001, \dagger)$ for both proteins in all the other groups. Differences in actual cpm/tube reflected the same changes (BSA, adults: $94 \pm 99$; newborns: $243 \pm 162 *$; 18 days old: 524 $\pm 193 \dagger ; \beta$-LG, adults: $431 \pm 100$; newborns: $763 \pm 122 \uparrow ; 18$ days old: $990 \pm 133 \dagger)$. $\mathrm{mg} / \mathrm{ml}$ of trace-labeled BSA and $\beta$-LG solutions. Using these concentrations of cold proteins, there was no saturation found (data not shown). Second, a constant concentration of the labeled solution $(0.1 \mu \mathrm{g} / \mathrm{ml})$ was incubated with MV protein concentrations between 0.1 and $4.0 \mathrm{mg} / \mathrm{ml}$ (Figs. 2 and 3). There was also no saturation phenomenon. The low percentage bound indicated weak binding of BSA and $\beta$-LG. Again, there was much more $\beta$ LG bound than BSA $(p<0.001$ for MVM protein concentrations above $0.5 \mathrm{mg} / \mathrm{ml}$, and for slope comparison in adult and newborn preparations). MVM preparations from newborn rats

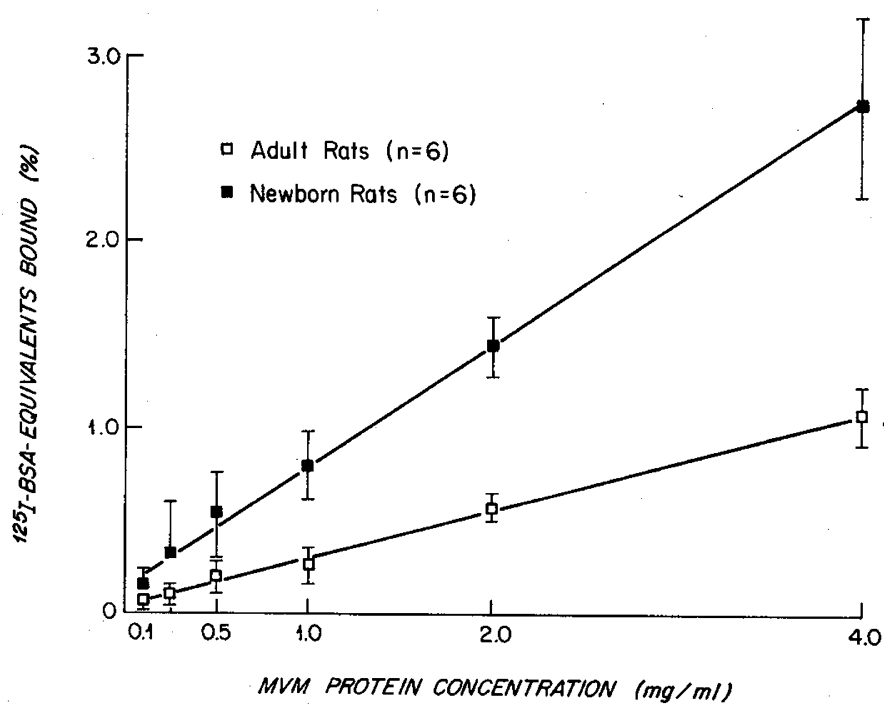

Fig. 2. Binding of ${ }^{125} \mathrm{I}-\mathrm{BSA}$ by jejunal MVM. Relation between MVM protein concentration and binding. Numbers of experiments for each concentration are given in parentheses. Means \pm SD are shown. BSA and $\beta$-LG concentration, $0.1 \mu \mathrm{g} / \mathrm{ml}$. Differences between adult and newborn MVM are statistically significant $(p<0.01)$ for MVM concentration at $0.5 \mathrm{mg} / \mathrm{ml}$ and highly significant $(\hat{p}<0.001)$ for MVM concentrations at $1.0,2.0$, and $4.0 \mathrm{mg} / \mathrm{ml}$. Difference of slopes between adult and newborn MVM were highly significant $(p<0.001)$. Differences in actual $\mathrm{cpm} /$ tube reflected the same changes (range, 50-400 in adults versus $240-1100$ in newborns).

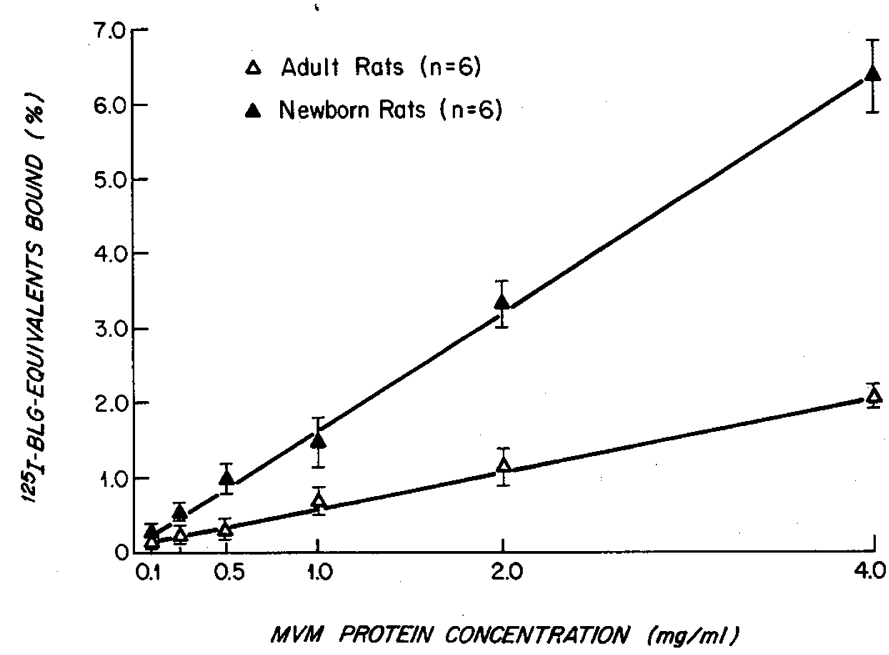

Fig. 3. Binding of ${ }^{125} I-\beta-L G$ by jejunal MVM. For details, see legend to Figure 2. Differences between adult and newborn MVM are statistically highly significant $(p<0.001)$ for MVM concentrations at 0.5 to $4.0 \mathrm{mg} / \mathrm{ml}$. Difference of slopes between adult and newborn MVM are highly significant $(p<0.001)$. Differences in actual $\mathrm{cpm} /$ tube reflected the same changes (range, 250-1300 in adults versus $920-2000$ in newborns). 
showed significantly more binding of BSA and $\beta$-LG than the adult ones ( $c f$. Fig. 1). Thus, using MVM preparations, more BSA and $\beta-\mathrm{LG}$ were bound in the immature animals, the binding being weak and nonspecific in terms of lacking saturation and inhibition.

Binding and uptake of BSA and $\beta-L G$ by everted gut sacs. Timed experiments from 1 to $30 \mathrm{~min}$ were carried out to detemine protein binding and uptake (Figs. 4 and 5). Binding and uptake of both proteins were significantly less in the immature animals, compared to adults. Much more $\beta$-LG was bound and taken up than BSA. This difference was statisticaly highly significant $(p<0.001)$ in both animal groups after 10,20 , and $30 \mathrm{~min}$. The absolute amount of BSA taken up was very low in both adult and preweanling sac preparations. Uptake and binding were shown to be correlated in the adult sacs $(r=0.57, p<0.01$, $n=24$ for ${ }^{125} \mathrm{I}$-BSA and $r=0.86, p<0.02, n=24$ for ${ }^{125} \mathrm{I}-\beta$-LG) and in the sacs prepared from 18-day-old rats $(r=0.76, p<$ $0.01, n=24$ for ${ }^{125}$ I-BSA and $r=0.85, p<0.001, n=24$ for $\left.{ }^{125} \mathrm{I}-\beta-\mathrm{LG}\right)$. These figures included uptake and binding of the intact protein as well as of its breakdown products (29).

To determine the degree of protein breakdown, TCA precipitation studies were done (Tables 1 and 2). As shown earlier for adult rats (29), there was much more breakdown of $\beta$-LG in the immature rats, compared to BSA $(p<0.001$ for both animal groups). As indicated by a higher percentage of TCA-precipitable radioactivity, there was less breakdown of BSA and $\beta$-LG in the 18-day-old rats, compared to adults. This was particularly shown in the material that had been taken up by the sacs. Thus, using the gut sac technique, less binding, breakdown, and uptake in parallel were found in the immature preweanling animals.

\section{DISCUSSION}

The present study has used two in vitro models of intestinal function to investigate handling and uptake of common food

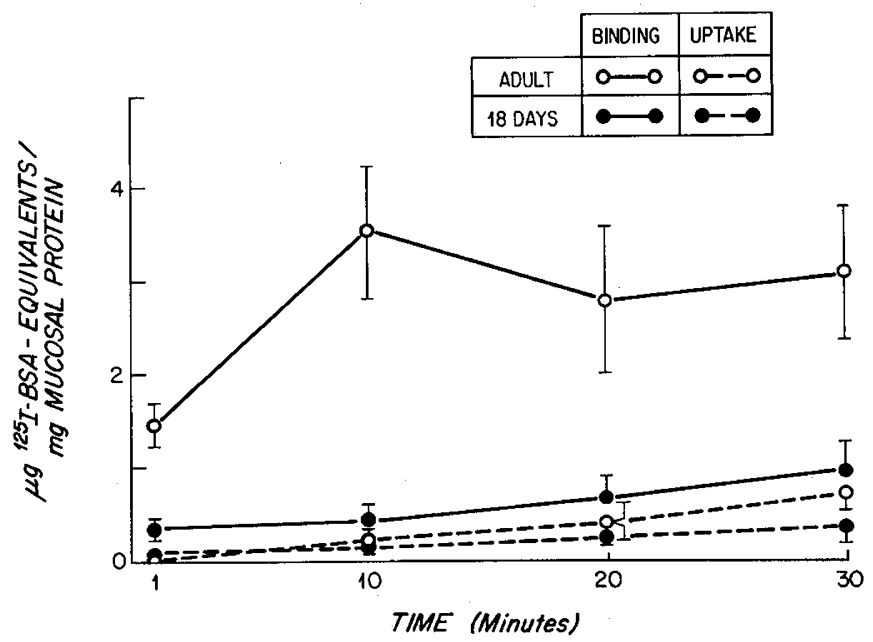

Fig. 4. Binding and uptake of ${ }^{125} \mathrm{I}-\mathrm{BSA}$ by gut sacs from adult $(n=$ 6 ) and 18-day-old rats $(n=12)$. Means \pm SD are given. Protein concentration, $1 \mathrm{mg} / \mathrm{ml}$. Differences in BSA binding between the animal groups are statistically highly significant $(p<0.001, *)$ after $1,10,20$, and 30 min. Difference in BSA uptake was significant only after $30 \mathrm{~min}(p<$ $0.01, \dagger)$. The same changes are reflected by the actual total $\mathrm{cpm} / \mathrm{mg}$ protein ( 1 min: binding $917 \pm 162$ in adults versus $218 \pm 62$ in 18-dayolds*; uptake, $12 \pm 12$ in adults versus $56 \pm 19$ in 18-day-olds; 10 min: binding, $2219 \pm 462$ in adults versus $268 \pm 94^{*}$; uptake, $137 \pm 94$ in adults versus $100 \pm 25 ; 20$ min: binding, $1741 \pm 493$ in adults versus $424 \pm 137^{*}$; uptake, $243 \pm 125$ in adults versus $150 \pm 50$; 30 min: binding, $1910 \pm 462$ in adults versus $587 \pm 187^{*}$; uptake, $443 \pm 125$ in adults versus $218 \pm 106 \dagger$. Means $\pm \mathrm{SD}$ are given for total $\mathrm{cpm} / \mathrm{mg}$ protein. (Unmarked values above are not significantly different between animal groups.)

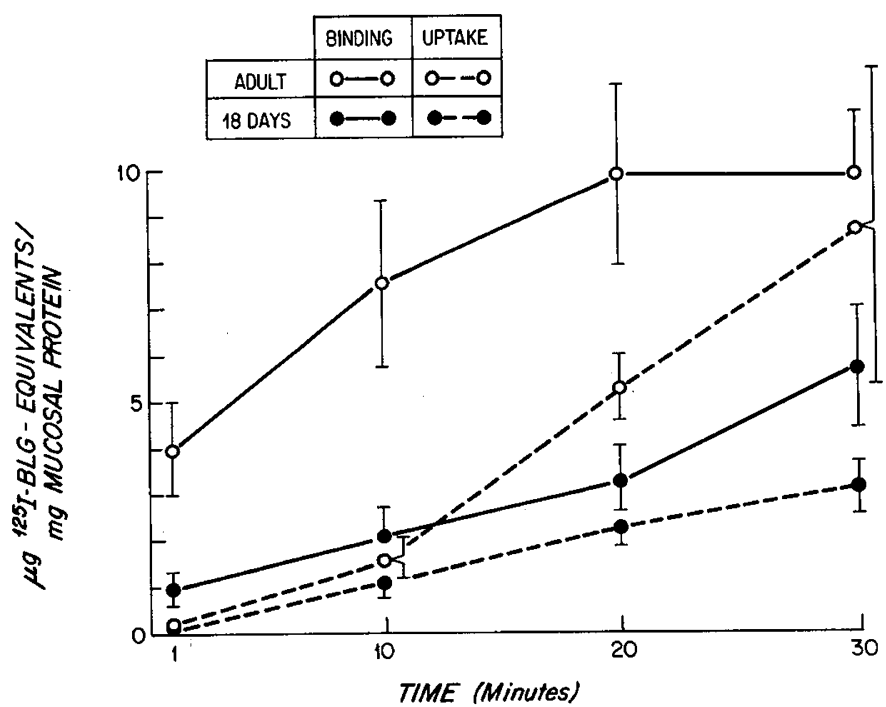

Fig. 5. Binding and uptake of ${ }^{125} \mathrm{I}-\beta-\mathrm{LG}$ gut sacs from adult and 18day-old rats. For details, see legend to Figure 4 . Differences between animal groups are statistically highly significant $\left(p<0.001,{ }^{*}\right)$ for binding after $1,10,20$, and $30 \mathrm{~min}$ and for uptake after 20 and $30 \mathrm{~min}$. The same changes are reflected by the actual total $\mathrm{cpm} / \mathrm{mg}$ protein $(1 \mathrm{~min}$ : binding, $2179 \pm 603$ in adults versús $525 \pm 171$ in 18-day-old animals $\dagger$; uptake, $66 \pm 61$ in adults versus $28 \pm 17$ in 18-day-old animals; 10 min: binding, $4154 \pm 1001$ in adults versus $151 \pm 348^{*}$; uptake, $879 \pm 232$ in adults versus $1814 \pm 431^{*}$; uptake, $2899 \pm 376$ in adults versus $1267 \pm$ 243*; 30 min: binding, $5439 \pm 736$ in adults versus $3103 \pm 819^{*}$; uptake, $4796 \pm 1919$ in adults versus $1704 \pm 326 ; p<0.01$ ).

Table 1. Binding and uptake of ${ }^{125}$ I-BSA by gut sacs from adult and 18-day-old rats: TCA precipitability of cpm bound and taken up (mean values for per cent TCA-precipitable cpm/total $c p m \pm S D)^{*}$

\begin{tabular}{ccc}
\hline & $\begin{array}{c}\text { Adult controls } \\
(n=6)\end{array}$ & $\begin{array}{c}\text { 18-day-old rats } \\
(n=6)\end{array}$ \\
\hline Binding & & \\
$1 \mathrm{~min}$ & $87 \pm 4$ & $86 \pm 4(\mathrm{NS})$ \\
$10 \mathrm{~min}$ & $86 \pm 4$ & $85 \pm 4(\mathrm{NS})$ \\
$20 \mathrm{~min}$ & $88 \pm 3$ & $86 \pm 4(\mathrm{NS})$ \\
$30 \mathrm{~min}$ & $88 \pm 1$ & $87 \pm 2(\mathrm{NS})$ \\
Uptake & $48 \pm 15$ & $75 \pm 9 \dagger$ \\
$1 \mathrm{~min}$ & $40 \pm 24$ & $73 \pm 8 \dagger$ \\
$10 \mathrm{~min}$ & $26 \pm 13$ & $56 \pm 14 \dagger$ \\
$20 \mathrm{~min}$ & $29 \pm 11$ & $55 \pm 8 \ddagger$ \\
$30 \mathrm{~min}$ & & \\
\hline
\end{tabular}

* For actual absolute values of total $\mathrm{cpm}$ from which the data were derived, see legend to Figure 4.

$\dagger p<0.01$.

$\ddagger p<0.001$.

proteins in young animals. First, MVM were prepared and tested for the microvillus surface characteristics of protein binding (26). Second, the more complete everted gut sac model $(34,36)$ was used to study the mucous coat component of the gut barrier protection against protein uptake. Both models previously have been shown to undergo maturational changes at early postnatal age $(11,22,27,34)$. Maturational changes are known to affect gut barrier functions at different levels: the gut lumen, the mucous coat and glycocalyx, and the enterocellular level. The immunophysiologic significance of these changes is of interest with respect to the uptake of potential food antigens in vulnerable neonates.

Previous studies in different species have shown early postnatal changes in the capacity of MVM to bind immunoglobulins (18), 
Table 2. Binding and uptake of ${ }^{125} I-\beta L G$ by gut sacs from adult and 18-day-old rats: TCA precipitability of cpm bound and taken up (mean values for per cent TCA-precipitable cpm/total cpm $\pm S D)^{*}$

\begin{tabular}{ccl}
\hline & $\begin{array}{c}\text { Adult controls } \\
(n=6)\end{array}$ & $\begin{array}{c}18 \text {-day-old rats } \\
(n=6)\end{array}$ \\
\hline Binding & $24 \pm 4$ & $29 \pm 3 \dagger$ \\
$1 \mathrm{~min}$ & $16 \pm 3$ & $12 \pm 2(\mathrm{NS})$ \\
$10 \mathrm{~min}$ & $19 \pm 7$ & $18 \pm 5(\mathrm{NS})$ \\
$20 \mathrm{~min}$ & $14 \pm 2$ & $25 \pm 6 \ddagger$ \\
$30 \mathrm{~min}$ & & \\
Uptake & $44 \pm 20$ & $41 \pm 15(\mathrm{NS})$ \\
$1 \mathrm{~min}$ & $8 \pm 3$ & $16 \pm 7 \dagger$ \\
$10 \mathrm{~min}$ & $7 \pm 4$ & $17 \pm 6 \dagger$ \\
$20 \mathrm{~min}$ & $7 \pm 3$ & $18 \pm 7 \ddagger$ \\
$30 \mathrm{~min}$ & &
\end{tabular}

${ }^{*}$ For actual absolute values of total $\mathrm{cpm}$ from which the data were derived, see legend to Figure 5.

$\dagger p<0.05$.

$\ddagger p<0.01$.

calcium (23), and lectins $(5,19)$. These studies involved specific binding of ligands and involved receptors which were saturable and specifically inhibited. In contrast, data obtained here showed that binding of cow's milk proteins to MVM was nonspecific and weak. These food proteins did not exhibit any lectin-like characteristics as have, for instance, been shown for soy proteins (2). Use of MVM allowed for the study of newborn as well as preweanling rats. Newborn preparations of MVM had a slightly yellow-greenish color as a sign of meconium contamination. The observation could possibly account for the decrease in binding observed in newborn animals compared to preweanlings. This effect underscores the possible inhibitive potential of substances overlying the MVM such as meconium or even mucus in decreasing protein binding to the membrane. Compared to adult animals, immature newborn and preweanling rats exhibited considerably more MVM surface binding of cow's milk proteins.

Specific small intestinal surface binding of substances such as enterotoxin (10) and cholera toxin (5), of pathogenic bacteria and their pili $(4,31)$, and of viruses (37) probably has wide clinical implications. It remains to be established if similar implications arise from nonspecific food protein binding to the intestinal surface which was shown in this study. Surface binding of food proteins could be an initial step in setting forward an adverse reaction in susceptible individuals. Susceptibility certainly is increased during the early postnatal period, a time when MVM binding of cow's milk proteins was shown to be increased in rats.

Throughout this study, in both models tested, more $\beta$-LG was bound to the mucous coat as well as to the surface component than was BSA. This confirmed earlier data (29). The difference was connected to differential protein breakdown which affected the intrinsic whey protein $\beta$-LG to a considerably greater degree than BSA. The difference in handling, even during the postnatal period, may have an impact on the role of single cow's milk proteins in causing tolerogenic or immunogenic effects in young individuals exposed to these proteins and to their fragments $(8$, $15,29,30)$. As our measurements included radioactivity representing the original protein and at the same time its breakdown products, there was no direct information on the uptake of antigenically intact macromolecules (33) from our data. In the gut sac model, it could be shown, however, that enzymatic protein breakdown was decreased in early age. This was likely to affect the uptake of intact food proteins which would then be present in larger quantities. An increased uptake of intact $\beta$-LG has been shown in premature human infants (24).

Earlier studies of macromolecular transport in everted gut sacs from neonatal rats (34) showed decreased uptake of horseradish peroxidase. We were able to confirm the decreased uptake in immature animals using cow's milk proteins. In contrast to the MVM preparation, the gut sac model has been used as a more complex model of intestinal antigen handling because it includes the mucous coat and cellular gut barrier components. The correlation between mucous coat protein binding and protein uptake which has been recently shown to exist in adult animals (29) was found to hold true for the immature animals. Mucous coat binding of BSA and $\beta-\mathrm{LG}$ was found to be nonspecific in terms of lacking saturation and inhibition, just as had been found for the MVM binding of the same proteins. Contrary to the data obtained with MVM, however, there was less binding of the proteins tested to the everted gut sacs prepared from immature rats, compared to adult controls.

A direct comparison between data obtained by the two models studied is not possible for obvious reasons. The isolated surface components of MVM are devoid of protecting elements of the mucosal barrier such as intestinal mucus $(28,35)$ and of lysosomal enzymes which are both represented in the gut sac model. There are different possible explanations for the observed differences between increased protein binding by immature MVM and decreased protein binding by immature gut sacs. The intestinal mucus layer is probably playing a role in reducing food protein binding and uptake in the gut sac model $(9,28,35)$. The role of protein breakdown by mucosa-associated enzymes which had been shown to be decreased in the immature rats could not be exactly defined in this study which did not allow differentiation between the binding and uptake of intact proteins from their breakdown products.

The reason for increased protein binding by immature MVM remains to be elucidated. Maturational changes in biochemical composition, membrane structure (22), or charge might be relevant in that respect. Physiological models like the gut sac and MVM proved to be useful for the study of interactions between food proteins and the small intestine. Studies will have to be extended to pathological conditions, such as experimental models of intestinal mucosal damage and altered immune status, before these interactions which are subject to considerable change during early postnatal maturation are fully understood in health and disease.

\section{REFERENCES}

1. Albers RW, Krishnan N 1979 Application of the miniature ultracentrifuge in receptor-binding assays. Anal Biochem 100:395. (See also Erratum, Anal Biochem 100:373, 1979)

2. Alvarez JR, Torres-Pinedo R 1982 Interactions of soybean lectin, soyasaponins, and glycinin with rabbit jejunal mucosa in vitro. Pediatr Res 16:728

3. Bahna SL, Heiner DC 1980 Allergies to Milk. Grune and Stratton, New York

4. Berendson R, Cheney CP, Schad PA, Boedeker EC 1983 Species-specific binding of purified pili (AF/R1) from the Escherichia coli RDEC-1 to rabbit intestinal mucosa. Gastroenterology 85:837

5. Bresson JL, Pang KY, Walker WA 1984 Microvillus membrane differentiation: quantitative difference in cholera toxin binding to the intestinal surface of newborn and adult rabbits. Pediatr Res 18:984

6. Cuatrecasas P 1971 Insulin-receptor interactions in adipose tissue cells: direct measurement and properties. Proc Natl Acad Sci USA 68:1264

7. Dahlquist A 1969 Assay of intestinal disaccharidases. Anal Biochem 22:99

8. Ferguson TA, Peters T, Reed R, Pesce AJ, Michael JG 1983 Immunoregulatory properties of antigenic fragments from bovine serum albumin. Cell Immunol $78: 1$

9. Forstner G, Wesley A, Forstner J 1982 Clinical aspects of gastrointestinal mucus. In: Chantler EN, Elder JB, Elstein $M$ (eds) Mucus in Health and Disease, vol II, p 199. Plenum Press, London

10. Giannella RA, Luttrell M, Thompson M 1983 Binding of Escherichia coli heat-stable enterotoxin to receptors on rat intestinal cell. Am J Physiol 245:G492

11. Henning SJ 1981 Postnatal development: coordination of feeding, digestion, and metabolism. Am J Physiol 241:G199

12. Hopfer U, Nelson K. Perotto J, Isselbacher KJ 1973 Glucose transport in isolated brush border membrane from rat small intestine. J Biol Chem 248:25

13. Jordan SM, Morgan EH 1968 The development of selectivity of protein absorption from the intestine during suckling in the rat. Aust $\mathrm{J}$ Exp Biol Med Sci 46:465

14. Kessler M, Acuto O, Storelli C, Murer H, Muller M, Semenza G 1978 A modified procedure for the rapid preparation of efficiently transporting vesicles from small intestinal brush border membranes. Their use in inves- 
tigating some properties of D-glucose and choline transport systems. Bichim Biophys Acta 506:136

15. Lebenthal E 1975 Cow's milk protein allergy. Pediatr Clin N Am 22:827

16. Lebenthal E, Lee PC 1983 Interactions of determinants in the ontogeny of the gastrointestinal tract: a unifed concept. Pediatr Res 17:19

17. Lowry OH, Rosebrough NJ, Farr AL, Randall RJ 1951 Protein measurement with the Folin phenol reagent. J Biol Chem 193:262

18. MacKenzie NM, Morris B, Morris R 1983 Protein binding to brush borders of enterocytes from the jejunum of the neonatal rat. Biochim Biophys Acta 755:205

19. Mahmood A, Torres-Pinedo R 1983 Postnatal changes in lectin binding to microvillus membranes from rat intestine. Biochem Biophys Res Commun 113:400

20. Markwell MAK, Fox CF 1978 Surface-specific iodination of membrane proteins of viruses and eucaryotic cells using 1,3,4,6-tetrachloro- $3 \alpha, 6 \alpha$-diphenylglycoluril. Biochemistry 17:4807

21. Moog F 1979 The differentiation and redifferentiation of the intestinal epithelium and its brush border membrane. CIBA Found Symp 70:31

22. Pang KY, Bresson JL, Walker WA 1983 Development of the gastrointestinal mucosal barrier. Evidence for structural differences in microvillus membranes from newborn and adult rabbits. Biochim Biophys Acta 727:201

23. Pang KY, Bresson JL, Walker WA 1983 Development of the gastrointestinal mucosal barrier. V. Comparative effect of calcium binding on microvillus membrane structure in newborn and adult rats. Pediatr Res 17:856

24. Reinhardt MC, Paganelli R, Levinsky RJ 1983 Intestinal antigen handling at mucosal surfaces in health and disease: humabn and experimental studies. Ann Allergy 51:311

25. Roberton DM, Paganelli R, Dinwiddie R, Levinsky RJ 1982 Milk antigen absorption in the preterm and term neonate. Arch Dis Child 57:369

26. Schmitz J, Preiser J, Maestracci D, Ghosh BK, Cerda JJ, Crane RK 1973 Purification of the human intestinal brush border membrane. Biochim Biophys Acta 323:98
27. Seetharam B, Yeh KY, Moog F, Alpers DH 1977 Development of intestinal brush border membrane proteins in the rat. Biochim Biophys Acta 470:424

28. Smithson KW, Millar DB, Jacobs LR, Gray GM 1981 Intestinal diffusion barrier: unstirred water layer or membrane surface mucous coat: Science 214:124

29. Stern M, Walker WA 1984 Food proteins and gut mucosal barrier. I. Binding and uptake of cow's milk proteins by the adult rat jejunum in vitro. Am J Physiol 246:G556

30. Strobel S, Mowat A, Drummond HE, Ferguson A 1981 Age at first feed influences immune response to fed antigen in mice. Pediatr Res 15:1193

31. Svanborg Eden C, Anderson B, Hagberg L, Hanson LA, Leffler J, Magnusson G. Moori G, Dahman J, Soderstrom $\Upsilon 1983$ Receptor analogues and antipili antibodies as inhibitors of bacterial attachment in vivo and in vitro. Ann NY Acad Sci 409:580

32. Telemo E, Westrom BR, Karlsson BW 1982 Proteolytic activity as a regulator of the transmission of orally fed proteins from the gut to the blood serum in the suckling rat. Biol Neonate $41: 85$

33. Udall JN, Pang K. Fritze L, Kleinman R, Walker WA 1981 Development of gastrointestinal mucosal barrier. I. The effect of age on intestinal permeability to macromolecules. Pediatr Res 15:241

34. Walker WA, Cornell R, Davenport LM, Isselbacher KJ 1972 Macromolecular absorption. Mechanism of horseradish peroxidase uptake and transport in adult and neonatal rat intestine. J Cell Biol 54:195

35. Walker WA, Isselbacher KJ, Bloch KJ 1974 Immunologic control of soluble protein absorption from the gut small intestine: a gut-surface phenomenon. Am J Clin Nutr 27:1434

36. Wilson TH, Wiseman G 1954 The use of sacs of everted small intestine for the study of the transference of substances from the mucosal to the serosal surface. J Physiol 123:116

37. Wolf JL, Kauffman RS, Finberg R, Dambrauskas R, Fields BN, Trier JS 1983 Determinants of reovirus interaction with the intestinal $M$ cells and absorptive cells of murine intestine. Gastroenterology 85:291

\title{
Lipases and Lipids in Human Milk: Effect of Freeze-Thawing and Storage
}

\author{
SUSAN E. BERKOW, LOIS M. FREED, MARGIT HAMOSH, JOEL BITMAN, D. LARRY WOOD, \\ BARBARA HAPP, AND PAUL HAMOSH
}

\begin{abstract}
Department of Pediatrics and Physiology and Biophysics, Georgetown University Medical Center, Washington, D. C. 20007 [S.E.B., L.M.F., M.H., B.H., P.H.], and Milk Secretion and Mastitis Laboratory, United States Department of Agriculture, Beltsville Agricultural Research Center, Beltsville, MD 20705 [J.B., D.L.W.]
\end{abstract}

\begin{abstract}
Frozen storage is often used by milk banks to preserve expressed human milk for later use. Optimal storage and handling conditions which ensure minimum alteration of lipid composition have not been well defined. Therefore we investigated the effect of rapid freeze-thawing and storage conditions $\left(-20\right.$ and $\left.-70^{\circ} \mathrm{C}\right)$ on the free fatty acid (FFA) levels and on the activities of lipoprotein lipase (LPL) and bile salt-stimulated lipase (BSSL) in human milk. Since during mechanical expression leakage of serum components into milk may occur, we also investigated the effect of the presence of serum on human milk LPL during storage. Lipase activity levels were unaffected by rapid freeze-thawing $(\times 3)$ followed by storage for 1 month at -20 or $-70^{\circ} \mathrm{C}$. LPL activity (nmol FFA released $/ \mathrm{ml} \mathrm{milk} /$
\end{abstract}

Received January 13, 1984; accepted May 22, 1984

Correspondence may be addressed to Dr. Margit Hamosh, Department of Pediatrics, Georgetown University Medical Center, 3800 Reservoir Road N. W. Washington, D. C. 20007.

This study was supported by National Institutes of Health Contract HD-2-2816. $\min$ ) was $414 \pm 128,451 \pm 37$, and $351 \pm 20$ and BSSL activity $(\mu \mathrm{mol} \mathrm{FFA} / \mathrm{ml} \mathrm{milk} / \mathrm{min})$ was $5.7 \pm 0.7,5.5 \pm 0.8$, and $5.7 \pm 0.2$ in fresh, freeze-thawed, and stored milk, respectively. FFA levels (\% of total lipid) were $3.01 \pm 1.05$ and $10.3 \pm 1.6$ in fresh-frozen milk stored at -70 and $-20^{\circ}$ $C$ for 5 months, and $3.78 \pm 1.08$ and $13.60 \pm 1.25$ in specimens of freeze-thawed $(\times 3)$ before storage at -70 or $-20^{\circ} \mathrm{C}$. Addition of serum had no effect on milk LPL at either temperature. We conclude that LPL and BSSL remain fully active during frozen storage of human milk and that milk fat is hydrolyzed at $-20^{\circ} \mathrm{C}$ but not at $-70^{\circ}$ C. We suggest that banked human milk be stored routinely at $-70^{\circ}$ C. (Pediatr Res 18:1257-1262, 1984)

\section{Abbreviations}

BSSL, bile salt-stimulated lipase

LPL, lipoprotein lipase

FFA, free fatty acids 